\title{
Evaluation The Anti-Inflammatory Effect of Prepared Aloe Vera Gel in Sulcular Full Thickness Flap Induced in Rats Model

\author{
Amal Hanna Aziz (MSc, PhD) ${ }^{1}$
}

${ }^{1}$ College of Dentistry, Hawler Medical University, Erbil, Iraq

email: amalnabaty@gmail.com

Received: 11 April 2021

Revised: 20 April 2021

Accepted: 30 May 2021

Published: 25 October 2021

Diyala Medical Journal 2021:21(1): 75-85

\section{Abstract}

Background: Aloe Vera contains many inorganic electrolytes like iron, potassium, chromium, copper, sodium, calcium, and zinc that are vital parts that induced the wound healing process as a result of the ability to prevent injury to the epithelium and promote healing of injured tissues. It improves healing by increasing the blood supply and oxygen to the area of injury tissue.

Objective: To evaluate the anti-inflammatory effect of Aloe Vera on wound healing in rats with full thickness flap and insertion of Aloe vera gel at the site of injury throughout analysis of the activity level of serum interleukin-1beta (IL-1 $\beta$ ).

Patients and Methods: Fifty five male rats were randomly divided into three groups: AAloe vera gel (25 rats), subdivided into (5) subgroups as a test group, B - Chlorhexidine gel (25 rats) was also subdivided randomly into (5) subgroups as a test group. Each subgroup (5rats) was exposed to surgery and filled with (AV) and CHX gel in both. C-non-surgical control group (5 rats) to obtain baseline data. A sulcular full thickness flap incision was carried out between the two maxillary central incisors. Blood samples for immunological studies were collected by cardiac puncture, at times $(3,5,7,10$, and 14 days) for estimation of serum (IL-1 $\beta$ ) levels using Indirect ELISA Technique in all groups.

Results: A highly significant decrease of serum IL- $1 \beta$ in rat group (A) within 3 and 5 days postsurgery, then the concentration of this cytokine started to increase on 7,10and 14days postsurgery, which is statistically non significantly affect with the control group (C), where it reaches the level of the control level before surgery.

Conclusion: Aloe vera shows anti-inflammatory effects by decreasing the inflammation of periodontal tissue post-surgery which could accelerate healing based on a significant increase in the level of serum (IL-1 $\beta$ ), reaching the control level before surgery at 14days, post-surgery that indicated positive results of this study. 
Keywords: Aloe Vera, chlorhexidine, pro-inflammatory (IL-1 $\beta$ ), surgical full thickness flap

\section{Introduction}

Aloe vera has traditionally been used to treat radiodermatitis, frostbite, psoriasis, and genital herpes infection[1].Antiinflammatory, antibacterial, antioxidant, antiviral, and antifungal properties are among its pharmacological behavior[2].The antiinflammatory, antibacterial, antioxidant, immune-boosting, and hypoglycemic properties of Aloe vera gel have been studied in vitro and in vivo[3].Aloe vera (AV) is a cactus-like perennial succulent from the Liliaceae family that is usually grown in tropical climates. (4.).It is one of the earliest medical agents that has been used to treat wounds[5].Since AV has an antiinflammatory function, it may be used to treat: gingivitis, periodontitis [6], skin wound [7], first to second degree burns[8] and a variety of other conditions. The use of (AV) as a topical agent has been shown to have a promising effect on wound healing[6]. A powerful healing effect of aloe vera gel was demonstrated in many research in the treatment of denture stomatitis, recurrent aphthous ulcers, oral lichen planus, cracked and split corners of the mouth throughout inhibition of the growth of Candida albicans, [9] in the oral cavity, in another study has been used in root canal treatment as a sedative dressing and lubrication during biomechanical preparation, this study supported by another study of the same author[9]. AV is used as a folk or traditional remedy for a variety of conditions; including diabetes, asthma, epilepsy and osteoarthritis, and also used topically for osteoarthritis, burns, sunburns and psoriasis[10].Many authors concluded that AV conducted that pain relieve and accelerate healing post periodontal flap surgery, by having good antiseptic and anti-inflammatory effect for treatment of gingivitis and periodontitis successfully, by reducing bleeding, control inflammation and stop the swelling of the gingival [11].Proteins, minerals, sugars, and vitamins are active ingredients found in aloe vera leaf extracts, considered as immunity regulator[12].Chlorhexidine is considered a gold standard in plaque removal, but side effects including tooth and tongue staining, altered taste sensitivity, and increased calculus formation make it difficult to use for extended periods of time. As a result, a naturally occurring, indigenous, and oral hygiene aid is needed. Aloe vera powder may be one of these remedies. It starts out as a 269-amino-acid-residue cytosolic precursor protein (pro-IL-1). The enzyme caspase 1 (IL-1 conversion enzyme, ICE) performs intracellular proteolysis to produce the active form of IL-1 with 153 amino acid residues, which is then released into the extracellular space [13]. Interleukins (ILs) are a type of cytokine with a wide range of immunological functions, including cell proliferation, migration, development, and differentiation. Interleukins may be pro- or antiinflammatory, and some of them function as chemokines or chemoattractants for other cells[14].

No research has looked at the relationship between aloe vera gel periodontal surgery and blood levels of a wide variety of cytokines measured by ELISA in patients. 
Periodontal inflammation and destruction may have a prognostic impact on the prevalence of potential events in these patients, according to these reports. Since AV has an anti-inflammatory function, it may be used to treat: gingivitis, periodontitis[6], skin wound, [7] first to second degree burns, [8] and a variety of other conditions. The use of AV as a topical agent has been shown to have a promising effect on wound healing[8]. In order to examine serum pro-inflammatory cytokine concentrations (IL-1ß) in rats with periodontal flap surgery after insertion of Aloe vera gel and chlorhexidine gel at the site of injury and their effect on wound healing progression, this research was carried out.

\section{Patients and Methods}

\section{settings and duration}

The control study was conducted at Hawler Medical University, Medical research center, College of Dentistry; The animals were kept in animal's house in the College of Medicine/Hawler Medical College for the period of June 2017 to November 2017.

\section{Chemicals and Reagents}

Rat IL-1B ELISA kit for estimation of serum interleukin-1beta (IL-1 $\beta$ ), KOMA BIOTECH INC.USA Aloe Vera's mature, safe and fresh 98\% (gel) Chlorhexidine 2\% (Periocare) gel (Kin company-Spanish).

\section{Animals, Experimental studies and sampling}

Fifty five male rats were used in this study with a body weight range of 150-200g. Before the trial, all of the animals were primed for one week at room temperature with a normal photoperiod. The duration of the experiment was 8weeks.

\section{Animals grouping}

Fifty five rats were used for this study. These (55) rats have been split arbitrarily into three different classes:

A- aloe vera gel was inserted into the performed surgical site test group, which consisted of (25) rats, B- chlorhexidine gel inserted into the surgical site test group, which consisted of (25) rats, and C- nonsurgical group which consisted of (5) rats), each group subdivided randomly into (5) subgroups. Each subgroup (5 rats). The surgical flap was carried out at the maxillary right and left central incisors. Before the surgery, the rats were weighed and anesthetized. Blood samples were collected by cardiac puncture, and the serum was prepared through centrifuging at $3000 \mathrm{rpm}$ for $10 \mathrm{~min}$ and was stored at $\left(-20^{\circ} \mathrm{C}\right)$ until time for immunological studies after specific time intervals of $(3,5,7,10$, and 14days), of $\mathrm{AV}$ gel and CHX gel inserted into the surgical site. Subgrouping post-surgery (A1, A2, A3, A4, and A5), (B1, B2, B3, B4 and $\mathrm{B} 5)$ of $\mathrm{AV}$ and $\mathrm{CHX}$ gel respectively.

\section{Surgical procedure}

A sulcular full thickness flap incision was carried out at the marginal gingival deep into the gingival sulcus and extends between the two maxillary right and left central incisors. This was carried out by using a scalpel blade No.15. The flap was reflected by the periosteal elevator. The surgical site was filled with aloe vera gel of $98 \%$ and considered as an experimental group. The surgical incision was filled with chlorhexidine gel $2 \%$ as a control group, and as a normal group, no surgical procedure was performed. The incision was sutured by one stitch with (4/0) black silk for a week. 


\section{Aloe Vera gel Preparation}

The mature, stable and fresh aloe vera was washed in flowing tap water, rinsed with sterile distilling water and lengthwise dissected, the colorless parenchymal tissue was removed with a sterile knife and extracted in a disposable syringe for insertion into the surgical site.

\section{Assessment of Immunological Parameters}

Serum (IL-1 $\beta$ ) levels in rat group with insertion of aloe vera gel inside crevicular full thickness flap, Serum cytokine (IL-1 $\beta$ ) levels in rat with insertion of chlorhexidine gel inside the sulcular full thickness flap and control nonsurgical group were estimated using Indirect ELISA technology.

\section{Statistical analysis}

SPSS version 22 was used to interpret the collected data. Mean, Standard deviation, and Tables are examples of descriptive statistics. Inferential statistics include: F-test and Ttest. Results were considered non-significant if $\mathrm{P}$ value $\geq 0.05$, significant if $\mathrm{P}$ value $\leq$ 0.05 , and highly significant if $\mathrm{P}$ value $\leq$ 0.000 .

Table (1): Comparison between the mean and standard deviation $( \pm \mathrm{SD})$ of serum $(\mathrm{IL}-1 \beta)$ concentration within sub groups of the Aloe vera and CHX gel

\begin{tabular}{|c|c|c|c|c|c|c|c|}
\hline $\begin{array}{c}\text { Rat } \\
\text { groups }\end{array}$ & Time/days & $\begin{array}{c}\text { No. of } \\
\text { Rats }\end{array}$ & $\begin{array}{l}\text { Serum IL-1 } \\
\text { mean }(\mathrm{pg} / \mathrm{ml})\end{array}$ & $\begin{array}{c}\text { Std. } \\
\text { Deviation }\end{array}$ & $\begin{array}{c}\mathrm{t} \text { t-test } \\
\text { (Independent) }\end{array}$ & P-Value & Si. \\
\hline \multirow{2}{*}{$\mathrm{AV}$} & A1 & 5 & 2.524 & 4.088 & \multirow{2}{*}{0.488} & \multirow{2}{*}{0.638} & \multirow{2}{*}{ (NS) } \\
\hline & $\overline{\mathrm{A} 2}$ & $\overline{\overline{55}}$ & 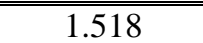 & 2.121 & & & \\
\hline \multirow{2}{*}{$\mathrm{CHX}$} & B1 & 5 & 2.178 & 3.056 & \multirow{2}{*}{-0.700} & \multirow{2}{*}{0.503} & \multirow{2}{*}{ (NS) } \\
\hline & $\overline{\mathrm{B} 2}$ & $\overline{55}$ & 4.236 & 5.815 & & & \\
\hline \multirow{2}{*}{ AV } & A1 & $\overline{5}$ & 2.524 & 4.088 & \multirow{2}{*}{-2.265} & \multirow{2}{*}{0.053} & \multirow{2}{*}{ (NS) } \\
\hline & A3 & 5 & 10.068 & 6.224 & & & \\
\hline \multirow{2}{*}{$\mathrm{CHX}$} & B1 & 5 & 2.178 & 3.056 & \multirow{2}{*}{-0.735} & \multirow{2}{*}{0.483} & \multirow{2}{*}{ (NS) } \\
\hline & $\overline{\text { B33 }}$ & $\overline{5}$ & 3.546 & 2.822 & & & \\
\hline \multirow{2}{*}{ AV } & A1 & 5 & 2.524 & 4.088 & \multirow{2}{*}{-3.322} & \multirow{2}{*}{0.011} & \multirow{2}{*}{$(\mathrm{S})$} \\
\hline & A4 & 5 & 12.450 & 5.284 & & & \\
\hline \multirow{2}{*}{ CHX } & $\mathrm{B} 1$ & 5 & 2.178 & 3.056 & \multirow{2}{*}{-1.857} & \multirow{2}{*}{0.100} & \multirow{2}{*}{ (NS) } \\
\hline & B4 & 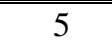 & $\overline{5.688}$ & 2.918 & & & \\
\hline $\mathrm{AV}$ & A1 & 5 & 2.524 & 4.088 & -6.260 & 0.000 & (HS) \\
\hline
\end{tabular}

\section{Results}

\section{Serum interleukein-1beta (IL-1ß)}

The descriptive statistics for mean and standard deviation (SD) are shown in Table (1) of the serum concentration of (IL-1 $\beta$ ) within one test surgical group with insertion of aloe vera and CHX gel (group A and B) at a different time intervals. The mean value of serum (IL-1 $\beta$ ), indicated a statistically significant difference between(AI and A4),respectively, (A2 and A3) in group A, while the mean value is a highly significant difference between A1 and A5 respectively, (A2 and A4), (A2 and A5).

CHX shows the descriptive statistics for $\mathrm{M}$ and $( \pm \mathrm{SD})$ of the serum concentration of (IL$1 \beta)$ concentration within one test surgical group with insertion of CHX gel (group B) at a different time intervals. The mean value of serum(IL-1 $\beta$ ), revealed a statistically significant difference between (B1 and B5), and respectively, (B3 and B5), and in group $\mathrm{B}$, while the mean value is non-significant between all remaining groups. 
Evaluation The Anti-Inflammatory Effect of Prepared Aloe Vera Gel in Sulcular Full Thickness Flap Induced in Rats Model

\begin{tabular}{|c|c|c|c|c|c|c|c|}
\hline & A5 & 5 & 16.944 & 3.134 & & & \\
\hline \multirow{2}{*}{ CHX } & B1 & 5 & 2.178 & 3.056 & \multirow{2}{*}{-2.847} & \multirow{2}{*}{0.022} & \multirow{2}{*}{ (S) } \\
\hline & B5 & $\overline{5}$ & 111.760 & 6.878 & & & \\
\hline \multirow{2}{*}{$\mathrm{AV}$} & $\mathrm{A} 2$ & 5 & 1.518 & 2.121 & \multirow{2}{*}{-2.908} & \multirow{2}{*}{0.020} & \multirow{2}{*}{ (S) } \\
\hline & A3 & 5 & 10.068 & 6.224 & & & \\
\hline \multirow{2}{*}{ CHX } & $\mathrm{B} 2$ & 5 & 4.236 & 5.815 & \multirow{2}{*}{0.239} & \multirow{2}{*}{0.817} & \multirow{2}{*}{ (NS) } \\
\hline & B3 & 5 & 3.546 & 2.822 & & & \\
\hline \multirow{2}{*}{$\mathrm{AV}$} & $\mathrm{A} 2$ & 5 & 1.518 & 2.121 & \multirow{2}{*}{-4.293} & \multirow{2}{*}{0.003} & \multirow{2}{*}{ (HS) } \\
\hline & A4 & 5 & 12.450 & 5.284 & & & \\
\hline \multirow{2}{*}{ CHX } & $\mathrm{B} 2$ & $\overline{5}$ & 4.236 & 5.815 & \multirow{2}{*}{-0.499} & \multirow{2}{*}{0.631} & \multirow{2}{*}{ (NS) } \\
\hline & B4 & 5 & 5.688 & 2.918 & & & \\
\hline \multirow{2}{*}{$\mathrm{AV}$} & A2 & 5 & 1.518 & 2.121 & \multirow{2}{*}{-9.115} & \multirow{2}{*}{0.000} & \multirow{2}{*}{ (HS) } \\
\hline & A5 & 5 & 16.944 & 3.134 & & & \\
\hline \multirow{2}{*}{ CHX } & B2 & 5 & 4.236 & 5.815 & \multirow{2}{*}{-1.868} & \multirow{2}{*}{0.099} & \multirow{2}{*}{ (NS) } \\
\hline & B5 & $\overline{5}$ & $\begin{array}{l}11.760 \\
\end{array}$ & 6.878 & & & \\
\hline \multirow{2}{*}{$\mathrm{AV}$} & A3 & $\overline{5}$ & 10.068 & 6.224 & \multirow{2}{*}{-0.652} & \multirow{2}{*}{0.532} & \multirow{2}{*}{ (NS) } \\
\hline & A4 & $\overline{5}$ & 12.450 & 5.284 & & & \\
\hline & B3 & 5 & 3.546 & 2.822 & & & \\
\hline CHX & B4 & 5 & 5.688 & 2.918 & -1.180 & 0.212 & (NS) \\
\hline & A3 & 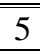 & 10.068 & 6.224 & & & \\
\hline AV & A5 & 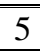 & 16.944 & 3.134 & -2.206 & 0.058 & (NS) \\
\hline & B3 & 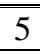 & 3.546 & 2.822 & & & \\
\hline CHX & B5 & 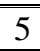 & 11.760 & 6.878 & -2.471 & 0.039 & (S) \\
\hline & A4 & 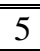 & 12.450 & 5.284 & & & \\
\hline AV & A5 & 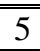 & 16.944 & 3.134 & -1.636 & 0.141 & (NS) \\
\hline & B4 & $\overline{5}$ & 5.688 & 2.918 & & & \\
\hline CHX & B5 & 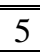 & 111.760 & 6.878 & -1.817 & 0.107 & $(\mathrm{NS})$ \\
\hline
\end{tabular}

Table (2) shows the descriptive statistics intervals. The results indicated that, a serum for mean $( \pm \mathrm{SD})$ of the serum concentration of IL-1 $\beta$ statistically non-significant difference (IL-1 $\beta$ ) concentration in two test surgical in all-time intervals in both $(\mathrm{A}$ and $\mathrm{B})$ rat groups with insertion of aloe vera gel (group groups except at day 10, there is significant A) and CHX gel (group B) at a different time difference between A4 and B4 respectively.

Table (2): The mean and standard deviation of serum interleukein-1beta (IL-1 $\beta$ ) concentration in 2 surgical groups with $98 \%$ aloe vera gel and $2 \%$ chlorhexidine gel at maxillary anterior region in different time interval

\begin{tabular}{|c|c|c|c|c|c|c|c|}
\hline Time/days & $\begin{array}{l}\text { Rats } \\
\text { groups }\end{array}$ & $\begin{array}{l}\text { No. } \\
\text { of } \\
\text { rats }\end{array}$ & $\begin{array}{l}\text { Serum IL-1 } \beta \\
\text { mean }(\mathrm{pg} / \mathrm{ml})\end{array}$ & $( \pm \mathrm{SD})$ & $\begin{array}{c}\text { t-test } \\
\text { (Independent) }\end{array}$ & P-Value & Sig* \\
\hline \multirow{2}{*}{3} & A1 & 5 & 2.524 & 4.088 & \multirow{2}{*}{0.152} & \multirow{2}{*}{0.883} & \multirow{2}{*}{ (NS) } \\
\hline & B1 & $\overline{5}$ & 2.178 & 3.056 & & & \\
\hline \multirow{2}{*}{5} & A2 & $\overline{5}$ & 1.518 & 2.121 & \multirow{2}{*}{-0.982} & \multirow{2}{*}{0.355} & \multirow{2}{*}{ (NS) } \\
\hline & $\mathrm{B} 2$ & $\overline{5}$ & 4.236 & 5.815 & & & \\
\hline \multirow{2}{*}{7} & A3 & 5 & 10.068 & 6.224 & \multirow{2}{*}{2.134} & \multirow{2}{*}{0.065} & \multirow{2}{*}{ (NS) } \\
\hline & B3 & 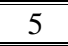 & 3.546 & 2.822 & & & \\
\hline \multirow{2}{*}{10} & A4 & 5 & 12.450 & 5.284 & \multirow{2}{*}{2.505} & \multirow{2}{*}{0.037} & \multirow{2}{*}{$(\mathrm{S})$} \\
\hline & B4 & 5 & 5.688 & 2.918 & & & \\
\hline \multirow{2}{*}{14} & A5 & $\overline{5}$ & 16.944 & 3.134 & \multirow{2}{*}{1.534} & \multirow{2}{*}{0.164} & \multirow{2}{*}{ (NS) } \\
\hline & B5 & 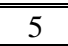 & 11.760 & 6.878 & & & \\
\hline
\end{tabular}


Table (3) shows the descriptive statistics for $\mathrm{M}$ and $( \pm \mathrm{SD})$ of the serum concentration of (IL-1 $\beta$ ) concentration in control non-surgical rats and two test surgical groups with insertion of $98 \%$ aloe vera gel and CHX. The results indicated that, serumIL-1 $\beta$ highly decrease significantly in rat group A with aloe vera gel inserted into the surgical site, 3days and 5days post-surgery (group A1 and A2), then the concentration of this cytokine started to increase reaching on 7days, 10days and 14days, after surgery (group A3, A4 and A5), which is statistically non significantly affect with the control non-surgical group (group C) where it reaches the level of the control group before surgery.

Table (3): The mean and standard deviation of serum interleukein-1beta (IL-1 $\beta$ ) concentration in control non-surgical group and surgical group with aloe vera gel at maxillary anterior region in different time intervals

\begin{tabular}{|c|c|c|c|c|c|c|c|}
\hline Time/days & $\begin{array}{l}\text { Rats } \\
\text { groups }\end{array}$ & $\begin{array}{l}\text { No. } \\
\text { of } \\
\text { rats }\end{array}$ & $\begin{array}{l}\text { Serum IL-1 } \beta \\
\text { mean (pg/ml) }\end{array}$ & $( \pm \mathrm{SD})$ & $\begin{array}{c}\text { t-test } \\
\text { (Independe } \\
\text { nt) }\end{array}$ & $\begin{array}{c}\text { P- } \\
\text { Value }\end{array}$ & Sig* \\
\hline \multirow{2}{*}{3} & A1 & 5 & 2.524 & 4.088 & \multirow{2}{*}{-3.399} & \multirow{2}{*}{0.009} & \multirow{2}{*}{ (HS) } \\
\hline & $\overline{\mathrm{C}}$ & 5 & 14.714 & 6.900 & & & \\
\hline \multirow{2}{*}{5} & $\overline{\mathrm{A} 2}$ & 5 & 1.518 & 2.121 & \multirow{2}{*}{-4.088} & \multirow{2}{*}{0.003} & \multirow{2}{*}{ (HS) } \\
\hline & $\mathrm{C}$ & 5 & 14.714 & 6.900 & & & \\
\hline \multirow{2}{*}{7} & A3 & 5 & 10.068 & 6.224 & \multirow{2}{*}{-1.118} & \multirow{2}{*}{0.296} & \multirow{2}{*}{ (NS) } \\
\hline & C & 5 & 14.714 & 6.900 & & & \\
\hline \multirow{2}{*}{10} & $\overline{\mathrm{A} 4}$ & $\overline{5}$ & 12.450 & 5.284 & \multirow{2}{*}{-0.583} & \multirow{2}{*}{0.576} & \multirow{2}{*}{ (NS) } \\
\hline & $\mathrm{C}$ & 5 & 14.714 & 6.900 & & & \\
\hline \multirow{2}{*}{14} & A5 & 5 & 16.944 & 3.134 & \multirow{2}{*}{0.658} & \multirow{2}{*}{0.529} & \multirow{2}{*}{ (NS) } \\
\hline & $\mathrm{C}$ & 5 & 14.714 & 6.900 & & & \\
\hline
\end{tabular}

Table (4) Shows the descriptive statistics for mean $( \pm \mathrm{SD})$ of serumIL-1 $\beta$ concentration in a control rat (group $\mathrm{C}$ ) and surgical groups with CHX gel (group B) in a different time intervals. The results showed that $\mathrm{CHX}$ gel have highly decreased significantly in serum IL-1 $\beta$ concentration on day 3 (B1), then significantly decrease on day5 (B2), day 7 (B3) and day10 (B4) after surgery, at the last on day 14 (B5) serum concentration of this cytokine started to statistically nonsignificant increase without reaching the concentration of the control group (group C). 
Table (4): The mean and standard deviation of serum interleukein-1beta (IL-1 $\beta$ ) concentration in control nonsurgical group and surgical group with $\mathrm{CHX}$ gel at maxillary anterior region at different time intervals

\begin{tabular}{|c|c|c|c|c|c|c|c|}
\hline $\begin{array}{c}\text { Time/ } \\
\text { days }\end{array}$ & $\begin{array}{l}\text { Rats } \\
\text { groups }\end{array}$ & $\begin{array}{l}\text { No. of } \\
\text { rats }\end{array}$ & $\begin{array}{l}\text { Serum IL-1 } \beta \\
\text { mean }(\mathrm{pg} / \mathrm{ml})\end{array}$ & $( \pm \mathrm{SD})$ & $\begin{array}{c}\mathrm{t} \text {-test } \\
\text { (Independent) }\end{array}$ & P-Value & Sig* \\
\hline \multirow{2}{*}{3} & B1 & 5 & 2.178 & 3.056 & \multirow{2}{*}{-3.714} & \multirow{2}{*}{0.006} & \multirow{2}{*}{ (HS) } \\
\hline & $\mathrm{C}$ & 5 & 14.714 & 6.900 & & & \\
\hline \multirow{2}{*}{5} & B2 & 5 & 4.236 & 5.815 & \multirow{2}{*}{-2.596} & \multirow{2}{*}{0.032} & \multirow{2}{*}{ (S) } \\
\hline & $\mathrm{C}$ & 5 & 14.714 & 6.900 & & & \\
\hline \multirow{2}{*}{7} & B3 & 5 & 3.546 & 2.822 & \multirow{2}{*}{-3.350} & \multirow{2}{*}{0.010} & \multirow{2}{*}{$(\mathrm{S})$} \\
\hline & $\mathrm{C}$ & 5 & 14.714 & 6.900 & & & \\
\hline \multirow{2}{*}{10} & B4 & 5 & 5.688 & 2.918 & \multirow{2}{*}{-2.694} & \multirow{2}{*}{0.027} & \multirow{2}{*}{$(\mathrm{S})$} \\
\hline & $\mathrm{C}$ & 5 & 14.714 & 6.900 & & & \\
\hline \multirow{2}{*}{14} & B5 & 5 & 11.760 & 6.878 & \multirow{2}{*}{-0.678} & \multirow{2}{*}{0.517} & \multirow{2}{*}{ (NS) } \\
\hline & $\mathrm{C}$ & 5 & 14.714 & 6.900 & & & \\
\hline
\end{tabular}

\section{Discussion}

Regarding surgical procedure performed in the periodontium of test group in rats, through using of a sharp blade to make the incision and then flap reflection by periosteal elevator. All steps involving in performing this procedure will consider as traumatic injury that induced to the periodontium and results in inflammation of the gingival tissue and cause destructions of collagen fibers of the periodontal ligament, the epithelial tissue and underlying connective cells become damaged, resulting in a collection of edema and fluid, swelling, increased cellular damage in the soft tissues of the periodontium and inflamed gingival tissues. This surgical technique is similar to that done in dogs by many authors in order to study the activity level of some serum enzymes during healing of the incision[15-17].These results are also in agreement with other studies [18-21] which concluded that injury and traumainduced in the brain of rats resulting in an inflammation of the tissue will change the activity level of some serum cytokines IL-1B, IL-6 and TNF-a, in this study we concluded that inflammation will start at 3, 5,7 days after surgery and destruction of periodontium and cells, then the inflammation will subside at the end of experiment 10,14 days posttreatment due to anti-inflammatory effect of using of (AV and $\mathrm{CHX}$ ) gel into a periodontal flap by reducing the inflammation of the periodontium after 14days post-surgery where the activity level of IL-1 $\beta$ in test group returns back to that in control level, where reaching the healing of injured tissue. This study agreement with the result of much research conducted on the healing effect of AV results [22, 23] from its ability to prevent injury to the gingival epithelium and promote healing and repair of injured tissues post-surgical flap [24] .Wound 
healing improves by increasing the blood supply to the surgical site [25].

We found in all of the serum samples that there was a significant increase in IL-1B level from the control (non-surgical) group to (14days after surgery). Our findings are in agreement with those of [26]. Plant sterols used in aloe vera are potent antiinflammatory agents. The wound did not show notable signs of inflammation and this as a result of the anti -inflammatory effects of Aloe vera[27]. This is also in agreement with[28], who indicated that Aloe vera can reduce edema by inhibiting the inflammatory response, not only by lowering the level of pro-inflammatory cytokines, but also by lowering leukocyte adhesion and penetration in the area of a wound or injury. There was an abundance of blood vessels at the dermalepidermal junction of the experimental animals and this suggests that Aloe vera plays a role in increased proliferation of blood vessels to the site of wound repair, to increase the vascularity to that region and also promote rapid healing.

This is similar to the research study conducted by [29] who discovered that Aloe vera increases neovascularization to the newly healed area[30] also reported that dermal dosage of Aloe vera mucilage on wound areas accelerated wound healing, contraction and thrombosis. Aloe vera was also shown to increase angiogenesis as well as granulated tissue and also better collagen rearrangement.

The result of [31], revealed that oral aloe vera gel extract has an antioxidative effect, as evidenced by a significant increase in serum nitric oxide and overall antioxidant ability. Aloe vera gel extract often produced naturally occurring antioxidant components such as complete phenols, flavonoids, vitamin $\mathrm{C}$, and vitamin $\mathrm{E}$, according to the findings. These antioxidant components are thought to be significant endogenous protection against oxidative cell and tissue damage since they specifically scavenge reactive oxidants [31]. Aloe vera gel contains $\mathrm{Cr}, \mathrm{Zn}$, and $\mathrm{Mn}$, according to the study. In addition [32, 33] concluded properties and chemical composition of aloe vera. Inorganic compounds like $\mathrm{Zn}, \mathrm{Cr}$, and $\mathrm{Mn}$, as well as vitamins like $\mathrm{E}$ and $\mathrm{C}$, are used in aloe vera gel extract. Aloe vera is a unique plant known to man, used throughout history for treating ulcers, dermatitis, burns, protection of gastric mucosa, also use as an antiinflammatory and antimicrobial agent [34].

\section{Conclusions}

In full-thickness surgical periodontal flap with insertion of aloe vera gel, aloe vera shows beneficial anti-inflammatory and antioxidant effects by reducing the inflammation significantly providing which could accelerate healing and might base on the significantly increased level of serum (IL-1B) reaching the level of the control group at 14 days, after surgery with the promising findings.

\section{Recommendations}

1-Further studies are needed for investigating the histopathological features of using Aloe Vera extract as sub gingival irrigation in the treatment of surgically created bone defects in area of the maxilla or the mandible in experimental animals.

2- There are several unknown parameters in the field of wound healing by using Aloe Vera extract as a mouthwash; including its 
effect on salivary components, biological and immunological features.

Source of funding: Nill.

Ethical clearance:The study was approved by the Academic Ethical Committee for Medical Research Ethics, College of Dentistry/ Hawler Medical University in 2020. Consent to participate was given by signing an informed Consent approval by the Committee for Medical Research Ethics.

\section{Conflict of interest: Nill}

\section{References}

[1]Vogler BK, Ernst E. Aloe vera: a systemic review of its clinical effectiveness. Br J Gen Pract (1999): 49(447):823-828.: https://pubmed.ncbi.nlm.nih.gov/10885091 [2]Ndhlala AR, Amoo SO, Stafford GI, Finnie JF, Van Staden J Antimicrobial, antiinflammatory and mutagenic investigation of the South African tree Aloe (Aloe barberae) J Ethnopharmacol. (2009).;124 (3):404-408 https://reference.medscape.com/medline/abst ract/19505552

[3]Reynolds T, Dweck AC. Aloe vera leaf gel: a review update. Journal of Ethnopharmacology. (1999); 68: 3-37. https://www.scirp.org/(Slz5mqp453edsnp55r rgjct55

[4]Dat AD, Poon F, Pham KB and Doust J. Aloe vera for treating acute and chronic wounds. Cochrane Database Syst Rev. (2012);2:CD008762.

https://www.scielo.br/scielo.php?script=sci [5]Ajmera N, Chatterjee A and Goyal V. Aloe vera: It's effect on gingivitis. J Indian Soc Periodontol; (2013). 17:4358. https://www.jisponline.com/article.asp?issn= 0972
[6]Gupta RK, Gupta D, Bhaskar DJ, Yadav A, Obaid $\mathrm{K}$ and Mishra S. Preliminary antiplaque efficacy of aloe vera mouthwash on 4 day plaque re-growth model: randomized control trial. Ethiop J Health Sci. (2014);

24:139-44 https://pubmed.ncbi.nlm.nih.gov/24795515 [7]Mendonca FA, Passarini Junior JR, Esquisatto MA, Mendonca JS, Franchini CC and Santos GMEffects of the application of Aloe vera (L.) and microcurrent on the healing of wounds surgically induced in Wistar rats. Acta Cir Bras. (2009). 24:150-5. https://www.ncbi.nlm.nih.gov/pubmed/19377 785

[8]Khorasani G, Hosseinimehr SJ, Azadbakht M, Zamani A and Mahdavi MR Aloe versus silver sulfadiazine creams for second-degree burns: a randomized controlled study. Surg Today (2009). 39:587-91. https://pubmed.ncbi.nlm.nih.gov/19562446 [9]Sujatha G, Kumar GS, Muruganandan J, Prasad TSAloe vera in dentistry. J. Clin. Diagn. Res. JCDR (2014) ; 8 (10): 1-2. https://pubmed.ncbi.nlm.nih.gov/25478478 [10]Karim B,Bhaskar DJ, Agali C, Gupta D, Gupta RK, Jain A, et.al., Effect of Aloe vera Mouthwash on Periodontal Health: Triple Blind Randomized Control Trial. Oral Health Dent Manag (2014); 13 (1): 6. https://pubmed.ncbi.nlm.nih.gov/24603910 [11]Maan A, Nazir A, Khan M, Ahmad T, Zia R, Murid M, et.al., The therapeutic properties and applications of Aloe vera: A review. J. Herb. Med (2018) https://doi.org/10.1016/j.hermed.2018.01.002 [12]A.M. Gressner Liver fibrosis: Perspectives in pathobiochemical research and clinical outlook, Eur. J. Clin. Chem. Clin. Biochem. (1991). 29, 293-311 
https://www.ncbi.nlm.nih.gov/pubmed/18929 52

[13]P. Piccioli and A. Rubartelli, The secretion of IL-1 $\beta$ and options for release," Seminars in Immunology, (2013)."vol. 25, no. 6, pp. 425-429,. View at Publisher• View at Google Scholar https://www.sciencedirect.com/science/articl e/abs/pii/S1044532313000882

[14]Brocker C, Thompson D, Matsumoto A, Nebert DW, Vasiliou V. Evolutionary divergence and functions of the human interleukin (IL) gene family. Hum Genomics; (2010)5:30,55.

https://humgenomics.biomedcentral.com/arti cles/10.1186/1479-7364-5-1-30

[15]Eugster S, Schawalder P, Gaschen F, Boerlin P. A prospective study of postoperative surgical site infections in dogs and cats. Vet Surg. (2004);33:542-50 https://pubmed.ncbi.nlm.nih.gov/15362994 [16]Eckersall PD, Bell R. Acute phase proteins: biomarkers of infection and inflammation in veterinary medicine. Vet $\mathrm{J}$. (2010); 185:23-7. https://pubmed.ncbi.nlm.nih.gov/20621712 [17]Michelle B. Christensen Thomas Eriksen and Mads Kjelgaard-Hansen C-reactive protein: quantitative marker of surgical trauma and post-surgical complications in dogs: a systematic review Acta Veterinaria Scandinavica(2015)

https://actavetscand.biomedcentral.com/articl es/10.1186/s13028-015-0164-5

[18]Copray JC, Mantingh I, Brouwer N, et al. Expression of interleukin-1 beta in rat dorsal root ganglia. J Neuroimmunol. (2001);118:203-211.

https://pubmed.ncbi.nlm.nih.gov/11498255 [19]Yan HQ, Banos MA, Herregodts P, et al.
Expression of interleukin (IL)-1 beta, IL-6 and their respective receptors in the normal rat brain and after injury. Eur $\mathbf{J}$ Immunol. (1992);22:2963-2971.

[20] Watkins LR, Wiertelak EP, Goehler LE, et al. Characterization of cytokine-induced hyperalgesia. Brain Res. (1994); 654:15-26. https://pubmed.ncbi.nlm.nih.gov/7982088 [21] Perkins MN, Kelly D. Interleukin-1 beta induced-desArg9bradykinin-mediated thermal hyperalgesia in the rat. Neuropharmacology. (1994); 33:657-660. https://pubmed.ncbi.nlm.nih.gov/7936101 [22]Somboonwong, J., Duansak, N.,. The therapeutic efficacy and properties of topical Aloe vera in thermal burns. J. Med. Assoc. (2004) Thail. Chotmaihet Thangphaet 87 Suppl 4, S69-78. https://pubmed.ncbi.nlm.nih.gov/21213486 [23]Tarameshloo, M., Norouzian, M., ZareinDolab, S., Dadpay, M., Mohsenifar, J., Gazor, R.,. Aloe vera gel and thyroid hormone cream may improve wound healing in Wistar rats. Anat. Cell Biol (2012). 45, 170-177.

https://www.ncbi.nlm.nih.gov/pubmed/23094 205

[24]Parthasarathy, G., Manickam, D., Venkatachalam, M., Gowthaman, P., K Evanjelene, V., 2016. Synthesis of Nano Particles From Aloe Vera Extract - Review Paper

https://www.researchgate.net/publication/311 660363

[25]Davis, R.H., Leitner, M.G., Russo, J.M., Byrne, M.E., Anti-inflammatory activity of Aloe vera against a spectrum of irritants. J. Am. Podiatr. Med. Assoc (1989.) 79, $263-$ 276.https://pubmed.ncbi.nlm.nih.gov/274648 5 [26]Mengling Zhan et al., The Serum Level 
of IL-1B Correlates with the Activity of Chronic Pulmonary Aspergillosis, Iowa City, IA 52242, USA (2018). scholar.google.co.in/citations?user=YlVy0dc AAAAJ

[27]Arend WP, Guthridge CJ. Biological role of interleukin 1 receptor antagonist isoforms. Annals of the Rheumatic Diseases (2000). 59:

60-64

https://ard.bmj.com/content/59/suppl_1/i60 [28] Ahmed A.M. Abdel Hamid and Mona FM Soliman Effect of topical Aloe vera on the process of healing of full thickness skin burn: a histological and immunohistochemical study, Journal of Histology \& Histopathology (2015) Vol2 (3) pp28.

https://www.hoajonline.com/histology/2055$091 \mathrm{X} / 2 / 3$

[29]Davis RH, Leither MG, Russo J and Byrne The Wound Healing and Topical Activity of Aloe vera, Journal of American Pediatric. Medical Association. (1973): 79: pp559-562 PMID: 2607423

DOI:10.7547/87507315-79-11-559

https://pubmed.ncbi.nlm.nih.gov/advanced [30]Ayman A, Tamer W, Walied A, Ahmed G, Tarek K and Mustafa S, Aloe vera gel facilitates reepithelialization of corneal alkali burn in normal and diabetic rats, Clinical Ophthalmology (2015): 9 2019-2026, PMCID:PMC4630191DOI:10.2147/OPTH.S 90778

https://pubmed.ncbi.nlm.nih.gov/26604672 [31]K.C.H Yadav, J. Ravi Kumar, S.I Basha, G.R.Deshmukh, Ravi G and B.Santhamm Wound Healing Activity Of Topical Application Of Aloe vera Gel In experimental animal models, International Journal of Pharma and Bio Sciences, (2012).
Vol3(2),

$\mathrm{pp}$

64-72

https://www.omicsonline.org/open-access-

journals-list.php

[32]Nwaoguikpe, R.N., W. Braide, T.I.N.

Ezejiofor, The effect of aloe vera plant (aloe barbadensis) (2010)

https://www.researchgate.net/publication/265 168612

[33]Joseph, B., S.J. Raj, Pharmacognostic and Phytochemical properties of aloe vera linn- an overview. International Journal of Pharmaceutical Sciences Review and Research, (2011). 4(2): 107-110. https://pubs.acs.org/journal/jnprdf

[34]Davis RH, DiDonato JJ, Hartman GM, Haas RC Anti-inflammatory and wound healing activity of a growth substance in Aloe vera. Am Pediatric Med Assoc; (1994). 84:

$77-81$.

https://pubmed.ncbi.nlm.nih.gov/8169808 